UDC 616.127-005.8-053.7-059: [616.12-02: 616.151.5] -07: 616.12-018.74

DOI: $10.21668 /$ health.risk/2020.2.13.eng

\title{
ASSESSING ENDOTHELIUM RESISTANCE TO THROMBUS FORMATION AS A POTENTIAL RISK FACTOR CAUSING RECURRENT CARDIOVASCULAR EVENTS IN YOUNG PATIENTS AFTER CARDIAC INFARCTION
}

\author{
I.A. Novikova, L.A. Nekrutenko, T.M. Lebedeva, A.V. Khachatryan \\ Perm State Medical University named after Academician E.A. Wagner, 26 Petropavlovskaya Str., Perm, \\ 614000, Russian Federation
}

Cardiac infarction is considered a disease more common for elderly people; despite that, up to $10 \%$ of all cardiac infarctions occur at a young age. Cardiac infarction has grave consequences both for mental health and future working capability of patients who had it. Approximately $15 \%$ patients who have had cardiac infarction have to face a recurrent cardiovascular event based on thrombus formation in spite of therapy. Our research goal was to assess endothelium homeostasis in patients after cardiac infarction being treated with double anti-thrombocyte therapy during out-patient rehabilitation and to reveal potential risks that could cause recurrent cardiovascular diseases. Overall, we examined 25 people aged from 18 to 45 who had cardiac infarction and were treated with invasive therapy aimed at eliminating ischemic heart disease. The therapy was emergency percutaneous coronary intervention and coronary artery stenting performed at Perm Clinical Cardiologic Clinic during a period from September 2018 to March 2019. Endothelial homeostasis was examined in 12 months after cardiac infarction.

We detected that, together with conventional risk factors, young patients after cardiac infarction had apparent changes in coagulation homeostasis (shorter activated partial thromboplastin time, shorter prothrombin time, an increase in fibrinogen concentration; greater aggregative activity of thrombocytes with adenosine-diphosphate; depressed Hageman-factordependent fibrinolysis. Nevertheless, there was no significant difference in aggregative activity of thrombosytes with ristocetin between the test and control groups. Therefore, in 12 months after cardiac infarction, young patients still ran high risks of recurrent cardiovascular events; those risks were caused both by significant prevalence of conventional risk factors and by high thrombogenic risk that persisted in spite of relevant anti-thrombus therapy.

Key words: cardiac infarction, young patients, recurrent cardiovascular events, risk factors, endothelial homeostasis, hyper-coagulation, thrombosis.

Cardiovascular diseases remain the leading cause of death all over the world. The forecasts state that by 2030 ischemic heart disease (IHD) will still hold the first place among 15 main reasons for population mortality [1]. Cardiac infarction (CI) is one of the gravest IHD outcomes; it can result in sudden cardiac death.

Up to $10 \%$ of all the infarctions occur at young age even though $\mathrm{CI}$ is considered to be more typical for elderly people $[2,3]$. When a young patient has CI, it usually leads to grave outcomes both for his or her mental health and for working ability in the future. Mortality risk grows by 74 times in comparison with healthy young people [4].

Over the last years serious progress has been made in treating patients with CI. A considerable decrease in mortality caused by this

(C) Novikova I.A., Nekrutenko L.A., Lebedeva T.M., Khachatryan A.V., 2020

Irina A. Novikova - External Researcher at the Department for Hospital Therapy (e-mail: Nurdus@yandex.ru; tel.: +7 (342) 239-31-88; ORCID: http://orcid.org/0000-0002-3968-6498).

Ludmila A. Nekrutenko - Doctor of Medical Sciences, Professor at the Department for Hospital Therapy (e-mail: lunekru@mail.ru; tel.: +7 (342) 239-31-88; ORCID: http://orcid.org/0000-0001-9151-8195).

Tatyana M. Lebedeva - Doctor of Medical Sciences, Professor at the Department for Public Health and Healthcare (e-mail: super.oziz@yandex.ru; tel.: +7 (342) 236-12-56; ORCID: http://orcid.org/0000-0003-3374-8982).

Armenui V. Khachatryan - Postgraduate Student at the Department for Hospital Therapy (e-mail: Khachatryan. armenui@mail.ru; tel.: +7 (342) 239-31-88; ORCID: http://orcid.org/0000-0001-9940-9428). 
pathology has been achieved due to widely implemented percutaneous coronary interventions (PCI) and secondary prevention activities that include double anti-thrombocyte therapy. Nevertheless, patients with CI in their case history run 6 times higher risks of recurrent cardiovascular events than patients without it [5]. Approximately $15 \%$ of patients with $\mathrm{CI}$ in their case history suffer a recurrent cardiovascular disease that happens due to thrombus formation in spite of anti-thrombocyte treatment [6].

Probability of an acute thrombotic event depends on a balance between susceptibility to thrombus formation and efficiency of endogenous thrombolytic processes. Thus, any disorder in fibrinolysis leads to elevated thrombosis risks [7]. And vice versa, if the fibrinolytic system counterbalances impacts exerted by thrombogenic factors, then a thrombus may not occur at all or, at least, may not result in long-term vessel occlusion [8].

Large vessels endothelium when being in its normal state inhibits adhesion and thrombocytes activation due to various mechanisms, either directly or indirectly via degradation of thrombocytes receptors antagonists. Endotheliocytes produce substances with anti-thrombotic potential such as nitrogen oxide (NO), thrombomodulin, prostanoids, and adenosine. When endothelium doesn't function properly, namely loses its anti-aggregation potential, it makes for atherosclerotic process development [9-12].

Nowadays, a lot of attention is being paid to how thrombocytes interact with intact endothelial surfaces and participate in atherosclerosis development. Thrombocytes may become involved into atherogenesis due to hydrodynamic stress exerting its influence on endothelium cells [13]. A classical way of thrombocytes involvement into blood stasis is interaction between $\mathrm{GPIb} / \mathrm{IX} / \mathrm{V}$ thrombocyte receptor complex components and active A1-domain of von Willebrand factor [14]. Von Willebrand factor is a large multi-dimensional glycoprotein that is synthesized by endothelium cells, sub-endothelial connective tissues, and by thrombocytes themselves though in smaller quantities [15, 16]. After being synthesized large quantities of von Willebrand factor are stored in Weibel-Palade bodies and are released from them after an endothelial cell is stimulated, in particular, as a response to damage, and it can be a sign that endothelial dysfunction has already occurred [17]. Von Willebrand factor production increases under hypoxia and impacts exerted on endothelium by anti-inflammation cytokines [18, 19]. Having bound themselves to von Willebrand factor, thrombocytes activate and a cascade of reaction occurs in them; this cascade ultimately results in thromboxane A2 synthesis and adenosine diphosphate (ADP) release. Thromboxane A2 and ADP initiate talin and $\alpha I I b \beta 3$ polymerization thus causing thrombocytes aggregation [20, 21]. Therefore, von Willebrand factor is a key component in blood stasis. Thrombocytes aggregation with ristocetin, a co-factor of von Willebrand factor, indirectly reflects von Willebrand factor quantity in blood plasma.

Endogenous fibrinolysis activation is a function performed by an endothelium cell that prevents local thrombus formation. Fibrinolytic activity violation leads to greater risks of thrombosis in patients suffering from cardiovascular diseases [22]. Research data indicate that patients with early cardiovascular events in their family case histories have denser fibrin clots that are more resistant to lysis [23].

Hageman factor (factor XII) is a glycoprotein that circulates in blood plasma as zymogen; it is activated due to a contact with a negatively charged surface. Hageman factor is structurally similar to other proteins with fibrinolytic activity such as plasminogen, tissue (t-PA) and urokinase (u-PA) plasminogen activator [24]. XII factor activates prekallikrein and thus induces fibrinolysis; prekallikrein in its turn decomposes single-stranded uPA into active double-stranded u-PA. Kallikrein that occurs in the process releases bradykinin out of high-molecular kininogen. Kallikrein and bradykinin promote t-PA re- 
lease [25]. XII factor also can directly activate plasminogen [7]. Disorders in Hagemandependent fibrinolysis make for thrombotic events development.

Therefore, thrombus formation assessment requires determining thrombocytes reactivity, endothelial function, and activity of endogenous thrombolytic processes.

Endothelium resistance to thrombus in long-term period in young patients with CI in their case history has not been given as much attention in the literature as traditional risk factors. Most research works concentrate on assessing blood stasis parameters only in an acute CI phase. Nevertheless, an attempt to determine individual risks of thrombotic events seems quite promising for treating such patients as it will allow optimizing therapy via targeted selection of medications and treatment duration.

Our research goal was to assess endothelial blood stasis parameters in patients who had CI and were treated with double antithrombocyte therapy at an out-patient department; another goal was to reveal potential risks of recurrent cardiovascular events.

Data and methods. We included 25 people aged from 18 to 45 into our research; they all had suffered $\mathrm{CI}$ and had been treated against IHD with emergency percutaneous coronary intervention and coronary arteries stenting at Perm Clinical Cardiologic Clinic over a period from September 2018 to March 2019. All the patients were prescribed relevant anti-thrombocyte therapy. Criteria for a patient being excluded from our research were as follows: systemic diseases, grave functional disorders in the liver and kidneys, acute conditions of any concomitant disease, heart rhythm disorders, pancreatic diabetes, thrombocytes concentration being lower than $100 \cdot 10^{9} / 1$, and diagnosed disorders in thrombocytes functioning. Our reference group was made up of 15 practically healthy volunteers aged from 18 to 45 .

Initial profiles of research participants are given in Table 1.

The reference group was comparable with the test group as per age and sex. Men pre- vailed among young patients who had suffered CI. $40 \%$ patients in the test group had overweight and $8 \%$ suffered from obesity; only $26.7 \%$ had overweight in the reference group. It should be noted that smokers accounted for a rather big share among patients with $\mathrm{CI}$, higher than $75 \%$ (whereas it was only $25 \%$ in the reference group); arterial hypertension and burden heredity as per early cardiovascular diseases were also more widely spread among patients with CI.

Table 1

Clinical and demographic profiles of participants in the research

\begin{tabular}{|l|c|c|}
\hline \multicolumn{1}{|c|}{ Parameter } & $\begin{array}{c}\text { Young patients } \\
\text { with CI } \\
(n=25)\end{array}$ & $\begin{array}{c}\text { Reference } \\
\text { group } \\
(n=15)\end{array}$ \\
\hline Average age & $37.5 \pm 7.1$ & $36.3 \pm 7.1$ \\
\hline Sex & $\begin{array}{c}\text { men } 84.0 \% \\
\text { women 16.0 \% }\end{array}$ & $\begin{array}{c}\text { men } 80.0 \% \\
\text { women } 20.0 \%\end{array}$ \\
\hline Height, m & $1.73 \pm 0.08$ & $1.75 \pm 0.1$ \\
\hline Weight, kg & $76.6 \pm 14.3$ & $72.4 \pm 10.0$ \\
\hline $\begin{array}{l}\text { Body mass index, } \\
\text { kg/m }{ }^{2}\end{array}$ & $25.5 \pm 3.3$ & $23.6 \pm 1.8$ \\
\hline Smoking status & $76.0 \%$ & $26.7 \%$ \\
\hline $\begin{array}{l}\text { Arterial } \\
\text { hypertension }\end{array}$ & $60.0 \%$ & $20.0 \%$ \\
\hline $\begin{array}{l}\text { Burdened } \\
\text { heredity }\end{array}$ & $72.0 \%$ & $33.3 \%$ \\
\hline $\begin{array}{l}\text { Total cholesterol, } \\
\text { mmol/1 }\end{array}$ & $3.6 \pm 0.8$ & $4.5 \pm 0.6$ \\
\hline LDLP, mmol/1 & $2.0 \pm 0.6$ & $2.4 \pm 0.7$ \\
\hline
\end{tabular}

$16 \%$ out of all the patients had already had CI, and $8 \%$ among them had had even two CIs. Antero-lateral and posterior CIs were the most prevailing in terms of CI localization (Figure 1). CI with ST elevation accounted for $70 \%$ of all cases; CI without ST elevation, $30 \%$.

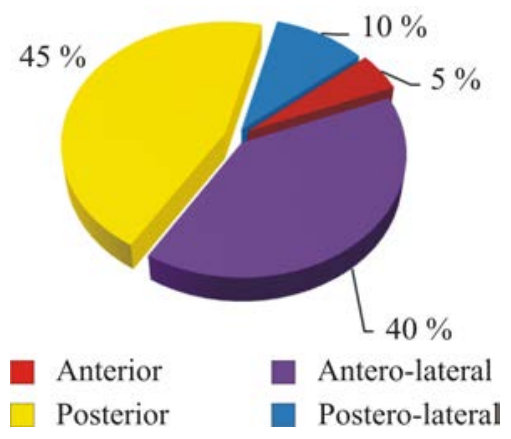

Figure 1. Cardiac infarction localizations 
All the patients underwent primary percutaneous coronary intervention; the procedure allowed revealing that $69 \%$ patients had two or more coronary arteries with stenosis exceeding $50 \%$ (Figure 2). Either the anterior inter-ventricular artery or the right coronary artery was symptom-dependent in most patients; those arteries are the largest among all coronary ones.

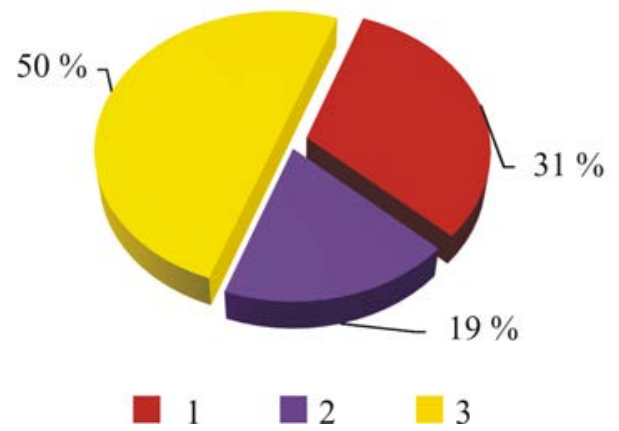

Figure 2. Number of damaged coronary arteries

$71.4 \%$ patients also had stenting procedure; in $40 \%$ cases stents covered with a medication were applied. According to some research works, peculiarities of stenting, in particular such parameters as stent diameter and overall length, exert their influence on risks of thrombosis in future [26]. In our research each third patient had a stent with its diameter being less than $3 \mathrm{~mm}$ and overall length of applied stents was more than $18 \mathrm{~mm}$ practically in all cases.

After being released from hospital, patients were recommended to take medications according to the latest clinical recommendations on treating patients with CI. Thus, angiotensin-converting enzyme (ACE) inhibitors / sartan drugs were prescribed to $80 \%$ patients; beta-blockers, to $88 \%$; statins in maximum doses and double anti-thrombocyte therapy including acetylsalicylic acid and P2Y12-thrombocyte receptors blocker, to all patients (Table 2).

Perindopril was the most frequently prescribed among all ACE inhibitors / sartans due to its great affinity with tissue ACE and it predetermined additional organ-protective properties of the drug [27]. The greatest share among prescribed beta-blockers belonged to cardioselective Bisoprosol; among P2Y12-thrombocyte receptors blockers, to Clopidogrel; among statins, to Atorvastatin. Commitment to therapy was close to $100 \%$ in our research. Therefore, all the patients were prescribed relevant therapy aimed at improving prognosis for the disease.

Table 2

Принимаемые лекарственные препараты

\begin{tabular}{|l|c|c|}
\hline \multicolumn{1}{|c|}{$\begin{array}{c}\text { Medications } \\
\text { group }\end{array}$} & $\begin{array}{c}\text { Active } \\
\text { ingredient }\end{array}$ & $\begin{array}{c}\text { A share of } \\
\text { prescription }\end{array}$ \\
\hline \multirow{4}{*}{$\begin{array}{l}\text { ACE inhibitors } \\
\text { sartan drugs }\end{array}$} & Perindopril & $70.0 \%$ \\
\cline { 2 - 3 } & Ramipril & $10.0 \%$ \\
\cline { 2 - 3 } & Losartan & $10.0 \%$ \\
\cline { 2 - 3 } & Valsartan & $5.0 \%$ \\
\hline \multirow{4}{*}{ Beta-blockers } & Telmisartan & $5.0 \%$ \\
\cline { 2 - 3 } & Metoprosol & $59.2 \%$ \\
\cline { 2 - 3 } & succinate & $31.8 \%$ \\
\cline { 2 - 3 } & Carvediol & $4.5 \%$ \\
\hline \multirow{2}{*}{$\begin{array}{l}\text { Acetylsalicylic } \\
\text { acid }\end{array}$} & Nebivolol & $4.5 \%$ \\
\hline $\begin{array}{l}\text { P2Y12-thrombo- } \\
\text { cytes receptors } \\
\text { blocker }\end{array}$ & Clopidogrel & $72.0 \%$ \\
\cline { 2 - 3 } & Ticagrelor & $24.0 \%$ \\
\hline \multirow{2}{*}{ Statins } & Prasugrel & $4.0 \%$ \\
\cline { 2 - 3 } & Atorvastatin & $84.0 \%$ \\
\hline
\end{tabular}

The research protocol was approved by the Local Ethical Committee at E.A, Vagners' Perm State Medical University of the RF Public Healthcare Ministry according to Helsinki Declaration (2008). All the patients included into the research gave their written voluntary informed consent to take part in it.

CI was diagnosed as per «Fourth Universal Definition of Myocardial Infarction» [28]. According to the WHO classification, age under 45 was considered young. Endothelial blood stasis was estimated 12 months after CI. Blood was taken from a patient on an empty stomach out of a peripheral vein into vacuum systems containing $3.2 \%$ solution of waterless sodium nitrate in ratio 1: 10. To determine aggregation of thrombocytes with ristocetin, we 
centrifuged blood samples at $200 \mathrm{~g}$ for $7 \mathrm{~min}$ utes and them collected plasma enriched with thrombocytes. Thrombocytes aggregation was examined as per Born method with «Biola» ALA-T2 laser thrombocytes aggregation analyzer. We determined blood fibrinolytic activity with Hageman-dependent fibrinolysis as per a procedure described by G.F. Eryomin and A.G. Arkhipov (1981, 1982). 12 months after CI frequency of a combined ultimate point was estimated; that point included cardiovascular death, recurrent $\mathrm{CI}$, and unstable stenocardia development.

All the data were statistically processed with Microsoft Excel and Stat Soft Statistica 13.0 applied statistical software. Quantitative parameters are given as simple mean \pm standard deviation; qualitative parameters are frequencies given in \%. Disprecpancies were considered statistically significant at $p \leq 0.05$.

Results and discussion. Table 3 contains the results obtained in laboratory assessment of blood stasis 12 months after CI.

Table 3

Blood stasis parameters in research participants

\begin{tabular}{|l|c|c|c|}
\hline \multicolumn{1}{|c|}{ Parameter } & $\begin{array}{c}\text { Young pa- } \\
\text { tients with CI } \\
(n=25)\end{array}$ & $\begin{array}{c}\text { Reference } \\
\text { group } \\
(n=15)\end{array}$ & $p$ \\
\hline APTT, sec & $28.5 \pm 2.8$ & $33.3 \pm 0.7$ & $<0.05$ \\
\hline PTT, sec & $13.7 \pm 0.7$ & $15.07 \pm 0.1$ & $<0.05$ \\
\hline TT, sec & $16.0 \pm 1.2$ & $18.53 \pm 1.0$ & $<0.05$ \\
\hline Fibrinogen, g/1 & $3.2 \pm 0.6$ & $2.94 \pm 0.1$ & $<0.05$ \\
\hline $\begin{array}{l}\text { Aggregation } \\
\text { of thrombocytes } \\
\text { with ADP, sec }\end{array}$ & $10.3 \pm 0.4$ & $14.9 \pm 0.2$ & $<0.05$ \\
\hline $\begin{array}{l}\text { Aggregation } \\
\text { of thrombocytes } \\
\text { with ristocetin, \% }\end{array}$ & $66.2 \pm 2.3$ & $64.3 \pm 3.1$ & $>0.05$ \\
\hline HDF, min & $12.0 \pm 3.6$ & $9.6 \pm 0.4$ & $<0.05$ \\
\hline
\end{tabular}

Patients with $\mathrm{CI}$ in their case history had more apparent changes in coagulation blood stasis system such as shorter activated partial thromboplastine time (APTT), shorter prothrombin time (PTT), shorter thrombin time (TT), and higher fibrinogen concentration.
Blood stasis disorders are a significant factor that influences rehabilitation after CI. Thus, it was shown in several research works that increased coagulation activity after PCI was related to higher risks of recurrent cardiovascular events such as re-stenosis or recurrent CI [29-31].

We examined aggregation function of thrombocytes with ADP and revealed a significant increase in their activity in patients who had suffered CI against healthy people (OR 4.4; 95 \% CI 1.5-12.0; $p<0.05$ ). Several prospective studies detected a relation between thrombocytes aggregation activity and cardiovascular event development in patients with diagnosed IHD [32, 33]. TRITON TIMI 38 and PLATO studied revealed that effective ADP-receptors inhibition improved a longterm prognosis for patients' survival rate $[34,35]$. A recent ADAPT-DES study showed that high residual thrombocytes reactivity against relevant therapy that included antagonists of P2Y12-thrombocytes receptors resulted in elevated risks of stent thrombosis, recurrent $\mathrm{CI}$, and mortality due to cardiovascular reasons [36].

We didn't reveal any significant differences between two groups regarding aggregation activity of thrombocytes with ristocetin in our research (OR 1.9; $95 \%$ CI 0.2-20.2; $p>0.05)$. Some research works showed that patients with CI had elevated von Willebrand factor concentration. Austrian scientists concluded that elevated von Willebrand factor concentration in patients with CI led to elevated risks of recurrent ischemic events [37]. A. Sambola et al. revealed a correlation between elevated von Willebrand factor concentration in blood plasma and thrombus resistance to fibrinolysis in patients with CI with ST elevation [38]. K. Ozawa et al., in their turn, revealed that an increase in endotheliumassociated von Willebrand factor concentration slowed down blood flow in the microcirculatory channel after CI [39]. Chinese researchers performed substantial meta-analysis aimed at estimating von Willebrand factor kinetics af- 
ter CI. It was detected that the highest von Willebrand factor concentration occurred during the $1^{\text {st }}$ week after $\mathrm{CI}$ and then it decreased gradually. It was detected that high von Willebrand factor concentration had prognostic significance and could be applied to estimate short-term prognosis [37].

Patients who had suffered CI had depressed Hageman-dependent fibrinolysis system. The discrepancy in this parameter was statistically authentic (OR 6.6; $95 \%$ CI 1.1-14.7; $p<0.05)$. Recent works consider weaker endogenous fibrinolysis to be an unfavorable prognostic marker in case there is acute coronary syndrome $[40,41]$. M. Farag et al. showed that patients who ran high cardiovascular risks still had functional disorders in their endogenous fibrinolysis 30 days after $\mathrm{CI}$; there was an assumption that endogenous fibrinolysis assessment after CI could help revealing patients who still ran high cardiovascular risks in spite of PCI and double anti-thrombocytes therapy [42]. Researchers from Perm also mention in their works that poorer fibrinolysis parameters in patients after CI have unfavorable prognostic signifi- cance [43]. Endogenous fibrinolysis is assumed to become a new target for medication therapy prescribed to patients with high cardiovascular risks [41].

Conclusions. 12 months after CI young patients still run high risks of recurrent cardiovascular events. In addition to traditional risk factors such as smoking, dyslipidemia, overweight, and family case history with early cardiovascular diseases, there is also high thrombogenic risk caused by grave damage to coronary lumen, stenting procedure peculiarities as well as apparent changes in blood stasis. Indirect assessment of von Willebrand factor concentration in patients receiving relevant double anti-thrombocyte therapy allows considering this parameter to become normal during rehabilitation after CI. Nevertheless, there is still a functional disorder in thrombocytes activity, proneness to hyper-coagulation, and endogenous fibrinolysis deterioration.

Funding. The research was not granted any sponsor support.

Conflict of interests. Authors state there is no any conflict of interests.

\section{References}

1. Mathers C.D., Loncar D. Projections of global mortality and burden of disease from 2002 to 2030. PLoS Med, 2006, vol. 3, no. 11, pp. 2011-2030. DOI: 10.1371/journal.pmed.0030442

2. Doughty M., Mehta R., Bruckman D., Das S., Karavite D., Tsai T., Eagle K. Acute myocardial infarction in the young - the University of Michigan experience. Am. Heart J., 2002, no. 143, pp. 56-62. DOI: $10.1067 / \mathrm{mhj} .2002 .120300$

3. Imazio M., Bobbio M., Bergerone S., Barlera S., Maggioni A.P. Clinical and epidemiological characteristics of juvenile myocardial infarction in Italy: the GISSI experience. G. Ital. Cardiol, 1998, no. 28 , pp. $505-512$.

4. Risgaard B., Nielsen J.B., Jabbari R., Haunsø S., Gaarsdal Holst A., Winkel B.G., Tfelt-Hansen J. Prior myocardial infarction in the young: predisposes to a high relative risk but low absolute risk of a sudden cardiac death. Europace, 2013, 15, pp. 48-54. DOI: 10.1093/europace/eus190

5. Cardiovascular diseases (CVDs). World Health Organization, 2017. Available at: http://www.who.int/mediacentre/factsheets/fs317/en/ (26.11.2019).

6. Giustino G., Mehran R., Dangas G.D., Kirtane A.J., Redfors B., Généreux P., Brener S.J., Prats J. [et al.]. Characterization of the average daily ischemic and bleeding risk after primary PCI for STEMI. J. Am. Coll. Cardiol, 2017, no. 70, pp. 1846-1857. DOI: 10.1016/j.jacc.2017.08.018

7. Okafor O., Gorog D. Endogenous fibrinolysis: an important mediator of thrombus formation and cardiovascular risk. J. Am. Coll. Cardiol, 2015, no. 65, pp. 1683-1699.DOI: 10.1016/j.jacc.2015.02.040

8. Leander K., Blomback M., Walle'n H., He S. Impaired fibrinolytic capacity and increased fibrin formation associate with myocardial infarction. Thromb. Haemost, 2012, no. 107, pp. 1092-1099. DOI: 10.1160/TH11-11-0760 
9. Davignon J., Ganz P. Role of endothelial dysfunction in atherosclerosis. Circulation, 2004, no. 109 , pp. 327-332. DOI: 10.1161/01.CIR.0000131515.03336.f8

10. Borissoff J.I., Spronk H.M., ten Cate H. The hemostatic system as a modulator of atherosclerosis. N. Engl. J. Med., 2011, vol. 364, no. 18, pp. 1746-1760. DOI: 10.1056/NEJMra1011670

11. Van Gils J.M., Zwaginga J.J., Hordijk P.L. Molecular and functional interactions among monocytes, platelets, and endothelial cells and their relevance for cardiovascular diseases. J. Leukoc. Biol., 2009, vol. 85, no. 2, pp. 195-204. DOI: 10.1189/jlb.0708400

12. Jin R.C., Voetsch B., Loscalzo J. Endogenous mechanisms of inhibition of platelet function. Microcirculation, 2005, vol. 12, no. 3, pp. 247-258. DOI: 10.1080/10739680590925493

13. Yago T., Lou J., Wu T., Yang J., Miner J.J., Coburn L., López J.A., Cruz M.A. [et al.]. Platelet glycoprotein Ibalpha forms catch bonds with human WT vWF but not with type 2B von Willebrand disease vWF. J. Clin. Invest, 2008, vol. 118, no. 9, pp. 3195-3207. DOI: 10.1172/JCI35754

14. Ruggeri Z.M. Von Willebrand factor, platelets and endothelial cell interactions. J. Thromb. Haemost, 2003, vol. 1, no. 7, pp. 1335-1342. DOI: 10.1046/j.1538-7836.2003.00260.x

15. Kanaji S., Fahs S.A., Shi Q., Haberichter S.L., Montgomery R.R. Contribution of platelet vs. endothelial VWF to platelet adhesion and hemostasis. J. Thromb. Haemost, 2012, no. 10, pp. 1646-1652. DOI: $10.1111 / j .1538-7836.2012 .04797 . x$

16. Yee A., Kretz C.A. Von Willebrand factor: form for function. Semin. Thromb. Hemost, 2014, no. 40, pp. 17-27. DOI: $10.1055 / \mathrm{s}-0033-1363155$

17. Boos C.J., Jaumdally R.J., MacFadyen R.J., Varma C., Lip G.Y.H. Circulating endothelial cells and von Willebrand factor as indices of endothelial damage/dysfunction in coronary artery disease: a comparison of central vs. peripheral levels and effects of coronary angioplasty. J. Thromb. Haemost, 2007, no. 5, pp. 630-632. DOI: 10.1111/j.1538-7836.2007.02341.x

18. Pinsky D.J., Naka Y., Liao H., Oz M.C., Wagner D.D., Mayadas T.N., Johnson R.C., Hynes R.O. [et al.]. Hypoxia-induced exocytosis of endothelial cell Weibel-Palade bodies. A mechanism for rapid neutrophil recruitment after cardiac preservation. J. Clin. Invest, 1996, no. 97, pp. 493-500. DOI: 10.1172/JCI118440

19. Zezos P., Papaioannou G., Nikolaidis N., Vasiliadis T., Giouleme O., Evgenidis N. Elevated plasma von Willebrand factor levels in patients with active ulcerative colitis reflect endothelial perturbation due to systemic inflammation. World J. Gastroenterol, 2005, no. 11, pp. 7639-7645. DOI: $10.3748 /$ wjg.v11.i48.7639

20. Lenting P.J., Christophe O.D., Denis C.V. Von Willebrand factor biosynthesis, secretion, and clearance: connecting the far ends. Blood, 2015, vol. 125, no. 13, pp. 2019-2028. DOI: 10.1182/blood-2014-06-528406

21. Li Z., Delaney M.K., O'Brien K.A., Du X. Signaling during platelet adhesion and activation. Arterioscler. Thromb. Vasc. Biol., 2010, vol. 30, no. 12, pp. 2341-2349. DOI: 10.1161/ATVBAHA.110.207522

22. Collet J.P., Allali Y., Lesty C., Tanguy M.L., Silvain J., Ankri A., Blanchet B., Dumaine R. [et al.]. Altered fibrin architecture is associated with hypofibrinolysis and premature coronary atherothrombosis. Arterioscler. Thromb. Vasc. Biol., 2006, vol. 26, pp. 2567-2573. DOI: 10.1161/01.ATV.0000241589.52950.4c

23. McMullen B.A., Fujikawa K. Amino acid sequence of the heavy chain of human a-factor XIIa (activated Hageman factor). J. Biol. Chem, 1985, no. 260, pp. 5328-5341.

24. Binnema D.J., Dooijewaard G., Turion P.N.C. An analysis of the activators of single-chain urokinase-type plasminogen activator (scu-PA) in the dextran sulphateeuglobulin fraction of normal plasma and of plasmas deficient in factor XII and prekallikrein. Thromb. Haemost, 1991, no. 65, pp. 144-148. DOI: $10.1055 / \mathrm{s}-0038-1647473$

25. Fuhrer G., Gallimore M.J., Heller W., Hoffmeister H.E. FXII. Blut, 1990, no. 61, pp. 258-266. DOI: $10.1007 / \mathrm{BF} 01732874$

26. Ganyukov V.I., Shilov A.A., Bokhan N.S., Moiseenkov G.V., Barbarash L.S. Prichiny trombozov stentov koronarnykh arterii [Reasons for thrombosis in coronary artery stents]. Mezhdunarodnyi Zhurnal interventsionnoi kardioangiologii, 2012, no. 28, pp. 29-34 (in Russian). 
27. Kukes V.G. Klinicheskaya farmakologiya [Clinical pharmacology]. Moscow, GEOTAR-Media Publ., 2008, pp. 392-395 (in Russian).

28. Thygesen K., Alpert J.S., Jaffe A.S., Chaitman B.R., Bax J.J., Morrow D.A., White H.D. [et al.]. Fourth universal definition of myocardial infarction. European Heart Journal, 2018, vol. 13, no. 138 (20), pp. e618-e651. DOI: 10.1161/CIR.0000000000000617

29. Kurtul A., Yarlioglues M., Murat S.N., Duran M., Oksuz F., Koseoglu C., Celik I.E., Kilic A. [et al.]. The association of plasma fibrinogen with the extent and complexity of coronary lesions in patients with acute coronary syndromes. Kardiol. Pol., 2016, no. 74, pp. 338-345. DOI: 10.5603/KP.a2015.0196

30. Lupi A., Secco G.G., Rognoni A., Rossi L., Lazzero M., Nardi F., Rolla R., Bellomo G. [et al.]. Plasma fibrinogen levels and restenosis after primary percutaneous coronary intervention. J. Thromb. Thrombolysis, 2012, no. 33, pp. 308-317. DOI: 10.1007/s11239-011-0628-z

31. Mahmud E., Behnamfar O., Lin F., Reeves R., Patel M., Ang L. [et al.]. Elevated serum fibrinogen is associated with 12-month major adverse cardiovascular events following percutaneous coronary intervention. J. Am. Coll. Cardiol, 2016, no. 67, pp. 2556-2557. DOI: 10.1016/j.jacc.2016.03.540

32. Trip M.D., Cats V.M., Van Capelle F.J., Vreeken J. Platelet hyperreactivity and prognosis in survivors of myocardial infarction. N. Engl. J. Med., 1990, no. 322, pp. 1549-1554. DOI: 10.1056/NEJM199005313222201

33. Gurbel P.A., Becker R.C., Mann K.G., Steinhubl S.R., Michelson A.D. Platelet function monitoring in patients with coronary artery disease. J. Am. Coll. Cardiol., 2007, no. 50, pp. 1822-1834. DOI: $10.1016 /$ j.jacc.2007.07.051

34. Wiviott S.D., Braunwald E., McCabe C.H., Montalescot G., Ruzyllo W., Gottlieb S., Neumann F.-J., Ardissino D. [et al.]. TRITON-TIMI 38 Investigators. Prasugel versus clopidogrel in patients with acute coronary syndromes. N. Engl. J. Med., 2007, no. 357, pp. 2001-2015. DOI: 10.1056/NEJMoa0706482

35. Wallentin L., Becker R.C., Budaj A., Cannon C.P., Emanuelsson H., Held C., Horrow J., Husted S. [et al.]. Ticagrelor versus clopidogrel in patients with acute coronary syndromes. N. Engl. J. Med., 2009, no. 361, pp. 1045-1057. DOI: 10.1056/NEJMoa0904327

36. Stuckey T.D., Kirtane A.J., Brodie B.R.,Witzenbichler B., Litherland C., Weisz G., Rinaldi M.J., Neumann F.-J. [et al.]. Impact of aspirin and clopidogrel hypo responsiveness in patients treated with drugeluting stents: 2-year results of a prospective, multicenter registry study. JACC Cardiovasc. Interv., 2017, no. 10, pp. 1607-1617. DOI: 10.1016/j.jcin.2017.05.059

37. Wang X., Zhao J., Zhang Y., Xue X., Yin J., Liao L., Xu C., Hou Y. [et al.]. Kinetics of plasma von Willebrand factor in acute myocardial infarction patients: a meta-analysis. Oncotarget, 2017, vol. 8, no. 52, pp. 90371-90379. DOI: 10.18632/oncotarget.20091

38. Sambola A., García Del Blanco B., Ruiz-Meana M., Francisco J., Barrabés J.A., Figueras J., Bañeras J., Otaegui I. [et al.]. Increased von Willebrand factor, P-selectin and fibrin content in occlusive thrombus resistant to lytic therapy. Thromb. Haemost, 2016, vol. 115, no. 6, pp. 1129-1137. DOI: 10.1160/TH15-12-0985

39. Ozawa K., Packwood W., Varlamov O., Qi Y., Xie A., Wu M.D., Ruggeri Z., López J. [et al.]. Molecular Imaging of VWF (von Willebrand Factor) and Platelet Adhesion in Postischemic Impaired Microvascular Reflow. Circ. Cardiovasc. Imaging, 2018, vol. 11, no. 11, pp. 1-9. DOI: 10.1161/CIRCIMAGING.118.007913

40. Saraf S., Christopoulos C., Salha I.B., Stott D.J., Gorog D.A. Impaired endogenous thrombolysis in acute coronary syndrome patients predicts cardiovascular death and nonfatal myocardial infarction. J. Am Coll. Cardiol, 2010, vol. 55, no. 19, pp. 2107-2115. DOI: 10.1016/j.jacc.2010.01.033

41. Christopoulos C., Farag M., Sullivan K., Wellsted D., Gorog D.A. Impaired thrombolytic status predicts adverse cardiac events in patients undergoing primary percutaneous coronary intervention. Thromb. Haemost, 2017, vol. 117, no. 3, pp. 457-470. DOI: 10.1160/TH16-09-0712

42. Farag M., Spinthakis N., Gue Y.X., Srinivasan M., Sullivan K., Wellsted D., Gorog D.A. Impaired endogenous fibrinolysis in ST-segment elevation myocardial infarction patients undergo- 
ing primary percutaneous coronary intervention is a predictor of recurrent cardiovascular events: the RISK PPCI study. European Heart Journal, 2019, vol. 40, no. 3, pp. 295-305. DOI: 10.1093/eurheartj/ehy656

43. Ryamzina I.N, Glebova S.A. Pokazateli gemostaza i lipidnogo profilya kak prediktory serdechno-sosudistoi smerti u bol'nykh, perenesshikh infarct miokarda [Parameters of homeostasis and lipid profile as predictors of cardiovascular death among patients who have had cardiac infarction]. Permskii meditsinskii zhurnal, 2003, vol. 20, no. 2, pp. $73-77$ (in Russian).

Novikova I.A., Nekrutenko L.A., Lebedeva T.M., Khachatryan A.V. Assessing endothelium resistance to thrombus formation as a potential risk factor causing recurrent cardiovascular events in young patients after cardiac infarction. Health Risk Analysis, 2020, no. 2, pp. 117-125. DOI: 10.21668/health.risk/2020.2.13.eng

Received: 06.04.2020

Accepted: 03.06.2020

Published: 30.06 .2020 